\title{
Development Models Of Fundamental Skill Exercise in Hockey
}

\author{
$1^{\text {st }}$ Syahputra Manik ${ }^{1}, 2^{\text {nd }}$ Ibrahim $^{2}$ \\ \{putramanik@unimed.ac.id'1 ,ibrahimhoki@unimed.ac.id² \\ Department of Sports Science, Faculty of Sports Science, Universitas Negeri Medan ${ }^{1,2}$ Medan, North \\ Sumatra, Indonesia
}

\begin{abstract}
Generally this research was purposes to produce models of fundamental skill exercise, specially dribble skill in hockey. This Research used qualitative approach and also applied methods of research \& development (R \& D). Subjects in this research are athletes of Unimed Hockey Club. Instruments which is used in this research are a). expert judgment. b). small group try-out. Based on the results of development can be concluded that: with the fundamental skill model development, athletes train more effectively, efficiently, and motivated.
\end{abstract}

Keywords: Development, models, fundamental, skill, dribble, hockey.

\section{Introduction}

Hockey is a sport game played between two teams where each player holds a stick to move the hockey ball. With the aim of creating as many goals as possible against the opponent's goal and keeping the goalpost itself from conceding the ball.

Hockey is a sport that is developing very rapidly within the Medan State University, that this university has become the center of hockey activities and development in North Sumatra, until now it has produced many achievements for Medan State University, North Sumatra and Indonesia. Medan State University Hockey club athletes have contributed greatly to many events such as National Championships, National Sports Week, Student Sports Week, ASEAN Student Sports Week and Sea Games.

The progress and development of hockey at the State University of Medan is certainly expected to contribute a lot in the creation of new findings in the form of better forms of exercise covering physical, technical and tactical/strategy and mental aspects. So that any problems encountered can be immediately overcome by continuing to improve themselves, by evaluating and improving in all supporting sectors and continuing to look for more effective and efficient methods or techniques to produce outstanding athletes who are ultimately expected to produce outstanding teams.

The game of hockey is basically an attempt to control the ball or win the ball back when it is under the control of the opponent. If the fundamental skill is mastered, then the ball is in control will be much longer in time. The players will also be more flexible to determine the course of the match and score against the opponent's goal.

Learning fundamental skills must be done in a targeted manner. How to play the ball and raise awareness of the motion of the ball, all of which can only be mastered by doing repeated, planned, measured and continuous exercises. 
Dribbling skills are used to move while keeping the ball, changing direction, creating space, avoiding opponents, preparing for passes and shots on goal and to slow down the tempo of the game. D.J. GIencross said the success of a player who was able to dribble had a great influence on the effectiveness and excitement of the game. Player performance is generally measured by the success of dribbling skills. Furthermore, Helen Ten and Haridas stated that there are three ways to check, namely: 1, open/loose dribble, 2 tightly check, 3 . Indian check.

\section{Methods}

The method used in this research is development research. The term research and development according to Nana Syaodid Sukmadinata is a process or steps to develop a new product or improve an existing product, which can be accounted for. According to Sugiono, there are educational products such as specific curricula for certain educational needs, learning methods, learning media, textbooks, modules, educational staff competencies, evaluation systems, competency test models, classroom arrangement for certain learning and others.

The final result of this research and development activity is an indian dribble training model for Unimed Hockey Club athletes. The final output of this research and development will result in the design of a new Indian dibble training model, complete with product specifications, so that it can be used as a reference in planning an exercise program. .

The research targets or users who are the targets of research on the development of the Indian dribble training model are athletes from Unimed Hockey Club, Medan State University, Medan North Sumatra with the following conditions:

1. Male athlete.

2. Medan State University Students.

3. Have participated in a national hockey championship.

4. Have mastered the fundamental skills of Indian dribble

\subsection{Model Development Planning}

The design for developing the Indian dribble training model in the hockey game quoted from Sadiman is as follows:

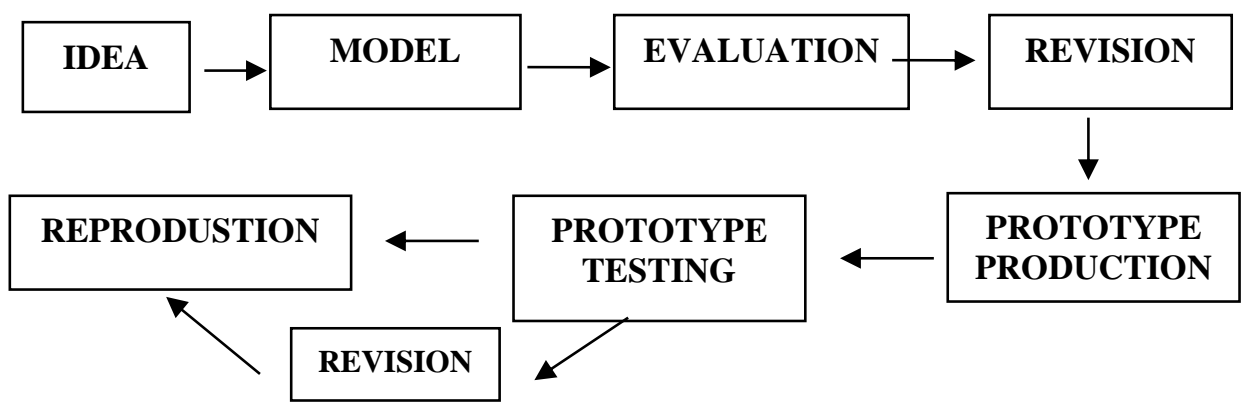

Fig. 1. Development model with flow chart. 
a. The first thing is determination of idea that will be developed, by collecting information as a rationale for making a concept.

b. Making a training model (product design), the form of the design is the Indian dribble training model.

c. Product revision 1 , the revision is carried out by the relevant expert.

d. Production of prototypes, carried out by practicing the training model

e. Indian dribble on the field.

f. Prototype testing, testing of field subjects in both phase I and phase II trials.

g. Revision of the second product, revisions are carried out by experts, in order to obtain

h. Perfect results.

i. Reproduction, product improvement to get to the final product expected in development

\section{Results \& Discussion}

The development model of the fundamental skill exercise in hockey was carried out at the Faculty of Sports Science, Medan State University, for students of the Sports Coaching Education Study Program with the subject of students specializing in hockey. Needs analysis was carried out with a subject of 30 students. The following are the results of the needs analysis obtained as follows:

Table 1. The results of needs analysis

\begin{tabular}{lllll}
\hline $\mathbf{N}$ & \multicolumn{1}{c}{ Questions } & Score & Total Score & \% \\
\hline $\mathbf{1}$ & $\begin{array}{l}\text { Do you think mastering the fundamental skills supports high } \\
\text { achievement in the game of hockey? }\end{array}$ & 30 & 30 & 100 \\
\hline $\mathbf{2}$ & Are you having trouble mastering fundamental skill? & 20 & 30 & 66,67 \\
\hline $\mathbf{3}$ & Do you want to master the fundamental skills of hockey well? & 30 & 30 & 100 \\
\hline $\mathbf{4}$ & $\begin{array}{l}\text { Do you think it is necessary to develop a fundamental skill exercise } \\
\text { model that you usually use? }\end{array}$ & 26 & 30 & 86,67 \\
\hline
\end{tabular}

\subsection{Product development}

The need analysis concluded that it was necessary to develop a model of fundamental skill hockey exercise for Medan State University Hockey Club athletes so that the achievements that have been achieved can be continuously improved. After getting the idea, the next step is to make an initial product in the form of a series of developing model of fundamental skill exercise in hockey which can later be used as input in the preparation of training programs at the Medan State University Hockey Club.

The initial product is set out in a hockey fundamental skill training model which is expected to be developed systematically and logically, so that this product has effectiveness and efficiency that deserves to be published. In making the product developed by the researcher, the researcher consulted the product with 2 sports experts and 2 hockey experts/coaches, to produce the perfect product. 
After making the hockey fundamental skill training model, the next step is to evaluate the hockey fundamental skill training model. The evaluation was carried out to improve and perfect the hockey fundamental skill training model that had been made.

\subsection{Evaluation}

The hockey fundamental skill training model that has been made and after being evaluated by experts, then undergone a phase I revision. The following is a summary of the revisions based on evaluations and suggestions from sports experts and hockey experts/coaches:

Table 2. Revision results from hockey experts/coaches.

\begin{tabular}{|c|c|c|c|c|c|c|c|c|}
\hline \multirow[t]{2}{*}{ NO } & \multirow[t]{2}{*}{ Aspects to rate } & \multicolumn{4}{|c|}{ Expert } & \multirow[t]{2}{*}{ Score } & \multirow{2}{*}{$\begin{array}{l}\text { Total } \\
\text { Score }\end{array}$} & \multirow[t]{2}{*}{$\%$} \\
\hline & & 1 & 2 & 3 & 4 & & & \\
\hline 1 & Model 1 & 4 & 4 & 4 & 4 & 16 & 16 & 100,00 \\
\hline 2 & Model 2 & 3 & 3 & 3 & 3 & 12 & 16 & 75,00 \\
\hline 3 & Model 3 & 4 & 4 & 3 & 4 & 15 & 16 & 93,75 \\
\hline 4 & Model 4 & 3 & 4 & 4 & 3 & 14 & 16 & 87,50 \\
\hline 5 & Model 5 & 3 & 3 & 3 & 4 & 13 & 16 & 81,25 \\
\hline 6 & Model 6 & 3 & 3 & 3 & 4 & 13 & 16 & 81,25 \\
\hline 7 & Model 7 & 4 & 3 & 4 & 3 & 14 & 16 & 87,50 \\
\hline 8 & Model 8 & 4 & 4 & 3 & 3 & 14 & 16 & 87,50 \\
\hline 9 & Model 9 & 4 & 4 & 3 & 3 & 14 & 16 & 87,50 \\
\hline 10 & Model 10 & 3 & 4 & 4 & 3 & 14 & 16 & 87,50 \\
\hline 11 & Model 11 & 3 & 4 & 4 & 4 & 15 & 16 & 93,75 \\
\hline 12 & Model 12 & 4 & 3 & 3 & 4 & 14 & 16 & 87,50 \\
\hline 13 & Model 13 & 3 & 3 & 3 & 4 & 13 & 16 & 81,25 \\
\hline 14 & Model 14 & 3 & 3 & 4 & 3 & 13 & 16 & 81,25 \\
\hline \multirow[t]{2}{*}{15} & Model 15 & 4 & 4 & 3 & 3 & 14 & 16 & 87,50 \\
\hline & & & & & & 208 & 240 & 86,67 \\
\hline
\end{tabular}

The results of the evaluation of 15 models of hockey fundamental skill training carried out by experts, overall obtained a score of 208 from a maximum score of 240 which means the average percentage of the evaluation results of the model is $86.67 \%$ and the development of the hockey fundamental skill training model is categorized as valid for use in development of a hockey fundamental skill training model for Medan State University Hockey Club athletes.

Based on the evaluation conducted by several experts, it can be concluded as follows:

a. The distance marking tool can be used to get a measured and adjusted workout to make it more interesting.

b. Most of the models used are appropriate for Medan State University Hockey Club athletes.

c. The preparation of the model from easy to more difficult levels, experts say it is well structured.

d. The expert stated that the effectiveness of the preparation of the hockey fundamental skill training model for Medan State University Hockey Club athletes was good for improving the fundamental skill ability. 


\subsection{Small Group Trial}

The figure 4 shows several web applications have been used by the general physics lectures with different percentage. This result shows that that capability of the lectures at Universitas Negeri Medan to support online class is sufficient. The percentage of lectures that using SIPDA application is $85 \%$.

Table 3. The results of small group trial.

\begin{tabular}{llccc}
\hline $\mathbf{N o}$ & Aspects To Rate & Score & Total Score & \% \\
\hline $\mathbf{1}$ & Model 1 & 65 & 80 & 81,25 \\
\hline $\mathbf{2}$ & Model 2 & 65 & 80 & 81,25 \\
\hline $\mathbf{3}$ & Model 3 & 70 & 80 & 87,50 \\
\hline $\mathbf{4}$ & Model 4 & 60 & 80 & 75,00 \\
\hline $\mathbf{5}$ & Model 5 & 61 & 80 & 76,25 \\
\hline $\mathbf{6}$ & Model 6 & 66 & 80 & 82,50 \\
\hline $\mathbf{7}$ & Model 7 & 66 & 80 & 82,50 \\
\hline $\mathbf{8}$ & Model 8 & 70 & 80 & 87,50 \\
\hline $\mathbf{9}$ & Model 9 & 70 & 80 & 87,50 \\
\hline $\mathbf{1 0}$ & Model 10 & 70 & 80 & 87,50 \\
\hline $\mathbf{1 1}$ & Model 11 & 63 & 80 & 78,75 \\
\hline $\mathbf{1 2}$ & Model 12 & 63 & 80 & 78,75 \\
\hline $\mathbf{1 3}$ & Model 13 & 65 & 80 & 81,25 \\
\hline $\mathbf{1 4}$ & Model 14 & 59 & 80 & 73,75 \\
\hline $\mathbf{1 5}$ & Model 15 & 67 & 80 & 83,75 \\
\hline & Sum & 980 & 1200 & 81,67 \\
\hline & & & & \\
\hline & & 67 & & \\
\hline
\end{tabular}

The results of small group trials on 15 models of fundamental skill hockey exercise given to 20 students specializing in hockey, overall it has been obtained a score of 980 from a maximum score of 1200 , which means the average percentage of model trial results in small groups is $81.67 \%$ and development the hockey fundamental skill training model is categorized as good for use in hockey fundamental skill training.

\section{Conclusion}

Based on the data obtained, from the results of field trials and discussion of research results, it can be concluded that: with the fundamental skill model development, athletes train more effectively, efficiently, and motivated. 
Acknowledgments. With the completion of this research, we would like to thank all those who have assisted and involved in this research. Thank you to the athletes, coaches and administrators of the Unimed hockey club. The researcher also expresses his gratitude to the promoter commission which has provided a lot of input and guidance during the completion of this research.

\section{References}

[1] Bompa, Tudor O. Theory and Methodology of Training; the Key to Athletic Performance. Dubuque, Lowa: Kendall/Hunt Publishing Company; 1990.

[2] Borg, W.R. dan Gall, M.D. Educational Research: An Introduction, Fifthy Edition. New York: Longman; 1989

[3] Burgess D. Training programming and prescription. In: Brukner P, Clarsen B, Cook J, Cool A, Crossley K, Hutchinson M, McCrory P, Bahr R, Khan K, editors. Brukner \& Khan's Clinical Sports Medicine: Injuries. 5th ed. Australia: McGraw-Hill Education; 2017.

[4] D.J. Glencross, Coaching Hockey: The Australian Way. South Melbroune Australian Hockey Association, 1984.

[5] David Whitaker, The Hockey . Workshop A Complete Game Guide. Marlborough : Croweod Pres Ltd; 1997.

[6] Elizabeth A, Myers S, Field H. Step to Success. Champaign: Human Kinetics Publishers inc; 1999.

[7] Helen T , Haridas MP, Hoki. Selangor Darul Ehsan: Pajar Bakti; 2006.

[8] Korey KMD. Sport Training Principles. Current Sports Medicine Reports. 2019; 18 (4)

[9] Paul S, Rand S, Stovak M, Hilgers MP. AMSSM Sports Medicine CAQ Study Guide. Monterey (CA): Healthy Learning; 2012.

[10] Powers SK, Howley ET. The physiology of training: effect on VO2 max, performance, homeostasis, and strength. In: Powers SK, Howley ET, editors. Exercise Physiology: Theory and Application to Fitness and Performance. 6th ed. New York (NY): McGraw-Hill; 2007.

[11] Ryan, M. Hockey Coaching Manual Australia. Australian hockey_association; 1992.

[12] Sugiono. Metode penelitian kuantitatif, kualitatif dan R \& D". Bandung: Alfabeta; 2008.

[13] Sukadiyanto. Pengantar Teori Dan Metodologi Melatih Fisik. Yogyakarta: FIK Uiversitas Negeri Yogyakarta; 2005

[14] Sutopo AH. Multimedia Interaktif dengan Flash. Yogyakarta: Graha Ilmu; 2003.

[15] Vincent KR, Vincent HK, Seto CK. Basic principles of exercise training and conditioning. In: O'Connor FG, Casa DJ, Davis BA, St. Pierre P, Sallis RE, Wilder RP, editors. ACSM's Sports Medicine: A Comprehensive Review. Philadelphia (PA): Wolters Kluwer; 2013. 